\title{
原著論文.
}

\section{クロニジン経ロ投与による テトラカイン脊椎麻酔の延長効果}

太田孝一*1 本間英司*1 並木昭義*2

\begin{abstract}
要旨 テトラカイン脊椎麻酔の麻醉前投薬として, クロニジン $(0.3 \mathrm{mg})$ を経口投与した場合, 麻酔 延長作用がみられるかどうかを検討した，麻酔レベルが 2 分節下降するのに要した時間は, 対照群 $69.4 \pm 11$ 分に対し, クロニジン群は $142.5 \pm 24$ 分と有意な $(\mathrm{p}<0.01)$ 延長が認められた. 4 分節下 降時間, Th10, $\mathrm{L}_{1}$ レベルへの下降時間および麻酔レベルの経時的変化についても有意な延長を示し た. 脊椎麻酔延長のため, これまで $\alpha$ 刺激薬のくも膜下投与が行われてきたが, クロニジンの経ロ 投与によっても同様の効果が認められることが明らかになった。今後の臨床使用が期待される.
\end{abstract}

$\alpha_{2}$ レセプタ刺激薬であるクロニジンは, 通常 の降圧薬と異なり, 中枢性の交感神経活動を抑 制することにより降圧作用を示すとされ ${ }^{1)}$, 鎮静 作用も有する2) ユニークな薬剤である。

またクロニジンは，ハロセンなどの吸入麻酔 薬の MAC を減少させたり ${ }^{3)}$, 低血圧麻酔時の二 トロプルシッドの必要量を減少させる4)ことが知 られている。そのため, 全身麻酔時の麻酔前投 薬としての臨床使用が検討されている5) 7).

一方，クロニジンをくも膜下投与した場合, テトラカインタ) およびブピバカイン9)による脊椎 麻酔を延長させることも報告されている，そこ で, 今回, テトラカイン脊椎麻酔時に, クロニ ジンを麻酔前投薬として経口投与した場合，春

*1市立釧路総合病院麻酔科

*2札幌医科大学麻酔学教室

受理日 1989.1 .24
椎麻酔作用を延長させるかどうかについて検討 した.

\section{I 対象および方法}

婦人科おび泌尿器科領域の手術を予定された ASA 分類 I（年齢40〜65歳）の16例を，対照群 （N=8）とクロニジン群（N=8）の 2 群に任意 に分けた。今回対象とした全症例に対して，術 前回診時に口頭で本研究の説明を行い, 患者の 同意を受けた。術前60分に，対照群ではトリア ゾラム $0.25 \mathrm{mg}$ を，クロニジン群では，クロニジ ン0.3mgを麻酔前投薬として経口投与した。くも 膜下穿刺は，側臥位にて， $\mathrm{L}_{3-4}$ 棘間より 25 ゲー ジ針を用いて行った。局所麻酔薬は，テトラカ イン $20 \mathrm{mg}$ を生理的食塩水 $4 \mathrm{~m} \ell に$ 溶解したものを $3 \mathrm{~m}$ 使用し, $0.33 \mathrm{~m} \ell /$ 秒の注入速度で投与した。 麻酔レベルの確認は, pin-prick 法にて, 薬剤投 
表 1 最高レベルと麻酔レベル下降時間

\begin{tabular}{|c|c|c|}
\hline & 対 照 群 & クロニジン群 \\
\hline 最高麻酔レベル & Th $7.9 \pm 1.8$ & Th7 $.6 \pm 0.7$ \\
\hline 2 分節下降時間(分) & $69.4 \pm 11.2$ & $142.5 \pm 24.0^{*}$ \\
\hline 4 分節下降時間(分) & $112.5 \pm 13.9$ & $225.0 \pm 33.1^{*}$ \\
\hline Th10下降時間(分) & $86.3 \pm 38.1$ & $151.9 \pm 37.1^{*}$ \\
\hline$L_{1}$ 下降時間(分) & $153.8 \pm 43.6$ & $280.6 \pm 39.5^{*}$ \\
\hline
\end{tabular}

平均値土標準偏差, $* \mathrm{p}<0.01$ 対照群 vs クロニジン群

与後15分間隔で $\mathrm{L}_{1}$ レベルに低下するまで行った。 術中鎮静の目的で, 全例にペンタゾシン $15 \mathrm{mg}$ 手術開始前に, 静脈内投与した。輸液は, 手術 室入室直後より乳酸加りンゲル液を $5 \sim 6 \mathrm{ml} / \mathrm{kg} /$ 時の速度にて開始し, 脊椎麻酔施行後 1 時間ま で続け，その後適宜調節した。

測定項目として，最高麻酔レベル，最高麻酔 レベルより 2 分節および 4 分節下降するのに要 した時間, Th10および $\mathrm{L}_{1}$ レベルまで麻酔レベル が下降するのに要した時間，さらに麻酔レベル の経時的変化についても検討した. 統計学的処 理は, 麻酔レベルの経時的な変動に対しては Mann-Whitney のU検定にて, その他のデータ に対しては, unpaired student $\mathrm{T}$ 検定にて行い, 危険率 $5 \%$ 以下のものを有意とした。データの 表記は，すべて平均值士標準偏差で行った。

\section{II 結 果}

対象の内訳は, 対照群で男 5 例, 女 3 例, クロ ニジン群で男女各 4 例であった。年齢は, 対照

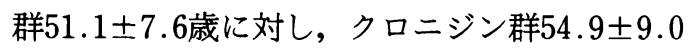
歳, 身長は, 対照群 $158.8 \pm 6.9 \mathrm{~cm}$ に対し, クロ ニジン群155.5土5.2cm, 体重は, 対照群 $62.3 \pm$ $8.3 \mathrm{~kg}$ に対し, クロニジン群 $58.8 \pm 9.2 \mathrm{~kg}$ であっ た. 年齢, 身長, 体重には両群間に差がなかつ た. 最高麻酔レベルと麻酔レベル下降時間を表
1 にまとめた。最高麻酔レベルは両群間に差が なかった。しかし， 2 分節下降および 4 分節下 降するのに要した時間, Th10および $\mathrm{L}_{1}$ レベルま で下降するのに要した時間は, 対照群に比べて クロニジン群が有意 $(\mathrm{p}<0.01)$ に延長した。麻 酔レベルの時間的推移については, 図 1 に示し た. 対照群では春椎麻酔後45〜60分頃より麻酔 レベルの下降が始まるのに対し, クロニジン群 では，105〜150分頃より麻酔レベルの下降が始 まった.このため, 脊椎麻酔後60分から90分ま では $5 \%$ \%下の危険率で，105分から180分まで は $1 \%$ 以下の危険率で, 対照群と比べて, クロ ニジン群が有意に麻酔レベルが高かった。

\section{III 考 察}

血管収縮薬は，局所麻酔薬への添加により， 脊椎麻酔の持続時間を延長したり，遮断効果を 高めることが知られている.その機序としては, くも膜下腔からの局所麻酔薬の吸収遅延ではな く, 脊髄の $\alpha$ レセプタ刺激作用 ${ }^{10)}$ や一過性虚 血 ${ }^{11)}$ の関与が考えられている.

さて,クロニジンはくも膜下に投与した場合, 脊椎麻酔の作用延長が認められ ${ }^{8)}$, 脊髄血流量 （SCBF）を軽度に減少させるが，組織損傷をき たさない12)ことなどから，その臨床使用が検討 され始めている9.

今回, クロニジンの経口投与を行ってみたと ころ，脊椎麻酔時間が約 2 倍に延長した。この 延長作用は, テトラカイン脊椎麻酔時に, フェ ニレフリンを添加した報告13),14) とほほ等しかっ た.クロニジン経口投与による脊椎麻酔延長作 用の機序は, くも膜下投与の場合と異なり, 高 濃度の血管収縮薬暴露がない点で，一過性虚血 の影響は受けないと思われる。クロニジンの降 圧作用は，中枢性に作用していることが知られ 


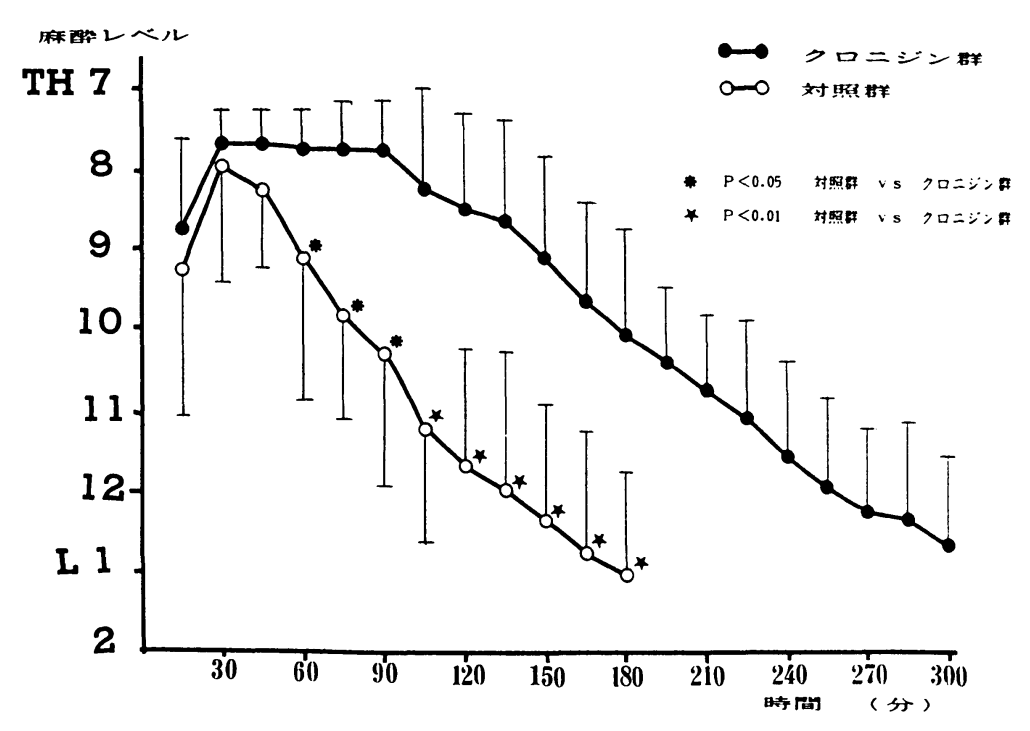

図 1 麻酔レベルの経時的変化(平均值士標準偏差)

ている ${ }^{15)}$.そのため,クロニジンの脊椎麻酔延長 作用の機序は, 脊髄レベルの $\alpha$ レセプタに対す る作用だけでなく，侵害刺激に対するノルアド レナリン系下行性神経系などの中枢神経の影響 も考えられる。

脊椎麻酔時の合併症として, 低血圧や徐脈が あり，脊椎麻酔の麻酔前投薬としてクロニジン が妥当かどうかは問題がある.しかし，クロニ ジンの降圧作用は, 健常人では本態性高血圧症 の患者より弱く ${ }^{16)}$, 起立性低血圧など体位による 血圧変動も少ないことが知られている ${ }^{17)}$.また, うっ血性心不全患者に対するクロニジン投与も 試みられ ${ }^{17)}$, その安全性がうかがえる.今回の著 者らの結果では, 脊椎麻酔施行前の収縮期血圧 は, 対照群 $133 \pm 13 \mathrm{mmHg}$ に対しクロニジン群は $127 \pm 16 \mathrm{mmHg}$ ，拡張期血圧は，対照群 $95 \pm 32$ $\mathrm{mmHg}$ に対しクロニジン群は78 $13 \mathrm{mmHg}$ ，心 拍数は, 対照群 $80 \pm 13 /$ 分に対しクロニジン群は $69 \pm 14$ /分と有意な差はなかった. また, 脊椎麻
酔後， $10 ， 20 ， 30 ， 60$ 分後の血圧および心拍数 についても両群間に差はなく, 昇圧剤を必要と した症例も 1 例もなかった. しかし, 対照群と 比べ徐脈傾向が，クロニジン群にみられた。

テトラカイン脊椎麻酔時に, 麻酔前投薬とし てクロニジン $(0.3 \mathrm{mg})$ 経口投与を行ったところ， 脊椎麻酔延長作用が認められた。その臨床使用 に際しては,クロニジン投与の適応および至適 量についてさらに検討すべき点も多いが，血管 収縮薬のくも膜下投与と比べ, SCBF の低下を 考慮しなくてもよいなどの利点もあり, 今後の 検討が待たれる。

\section{参考文献}

1) Langer SZ, Cavero I, Massingham R : Recent developments in noradrenergic neurotransmission and its relevance to the mechanism of action of certain antihypertensive agents. Hypertension $2: 372 \sim 382$, 1980

2) Johnson BF, McConachie NA: Hypotensive drugs. in Drugs for Heart Disease. edited by Hamer J, Chap- 
man and Hill Co., London, 1979, pp394 398

3 ) Bloor BC, Flacke WE: Reduction in halothane anesthetic requirement by clonidine, an alphaadrenergic agonist. Anesthesia and Analgesia 61 : 741 745, 1982

4) Bloor BC, Finander LS, Flacke WE, et al.: Effect of clonidine on sympathoadrenal response during sodium nitroprusside hypotension. Anesthesia and Analgesia 65:469 474, 1986

5 ) Flacke JW, Bloor BC, Flacke WE, et al. : Reduced narcotic requirement by clonidine with improved hemodynamic and adrenergic stability in patients undergoing coronary bypass surgery. Anesthesiology $67: 11 \sim 19,1987$

6 ) Ghignone M, Quintin L, Duke PC, et al. : Effects of clonidine on narcotic requirement of fentanyl anesthesia and endotracheal intubation. Anesthesiology $64: 36 \sim 42,1986$

7) Pouttu J, Scheinin B, Rosenberg PH, et al.: Oral premedication with clonidine: Effects on stress responses during general anesthesia. Acta Anaesthesiol Scand $31: 730 \sim 734,1987$

8 ) Mensink FJ, Kozody R, Kehler $\mathrm{CH}$, et al.: Doseresponse relationship of clonidine in tetracaine spinal anesthesia. Anesthesiology $67: 717 \sim 721,1987$

9 ) Racle JP, Benkhadra A, Poy JY, et al. : Prolongation of isobaric bupivacaine spinal anesthesia with epinephrine and clonidine for hip surgery in the elderly. Anesthesia and Analgesia 66:442 446, 1987

10) Ruddy SVR, Maderdrut JL, Yaksh TL: Spinal cord pharmacology of adrenergic agonist mediate antinociception. J Pharmacol Exp Ther 213: 525 533, 1980

11) Denson DD, Bridenbaugh PD, Turner PA, et al.: Neural blockade and pharmacokinetics following subarachinoid lidocaine in the Rhesus monkey. I. Effects of epinephrine. Anesthesia and Analgesia $61: 746 \sim 750,1982$

12) Gordh Jr T, Post C, Olsson $Y$ : Evaluation of the toxicity of subarachnoid clonidine, guanfacine, and a substance $\mathrm{P}$-antagonist on rat spinal cord and nerve roots. Anesthesia and Analgesia $65: 1303 \sim 1311$, 1986

13) Conception M, Maddi R, Francis D, et al.: Vasoconstrictors in spinal anesthesia with tetracaine-a comparison of epinephrine and phenylephrine. Anesthesia and Analgesia $63: 134 \sim 138,1984$

14）太田孝一, 並木昭義, 今泉 均ほか：テトラカイン脊椎麻 酔におけるフェニレフリンの鎮痛持続時間および鎮痛効 果に及ほす影響. 麻酔 $34: 1499 \sim 1504,1985$

15）荻野耕一：クロニジンと中枢性交感神経遮断剂. 臨床麻 酔 $5: 1434 \sim 1443,1981$

16) Goldstein DS, Levinson PD, Zimlichman $R$, et al. :
Clonidine suppression testing in essential hypertension. Annals of Internal Medicine 102: 42 48, 1985

17) Ren JH, Unverferth DV, Magorien RD, et al. : Postual influences on the hemodynamic responses to vasodilating drugs in congestive heart failure. Arch Intern Med $145 ; 641 \sim 644,1985$

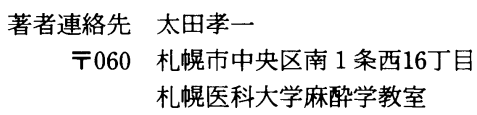
札幌医科大学麻酔学教室 


\title{
Prolongation of Isobaric Tetracaine Spinal Anesthesia in Oral Clonidine Premedication
}

\author{
Kouichi OTA*, Eiji HONMA*, Akiyoshi NAMIKI** \\ *Department of Anesthesia, Kushiro Municiple General Hospital \\ **Department of Anesthesiology, Sapporo Medical Collage and Hospital
}

The effects of oral clonidine on the duration of isobaric tetracaine spinal anesthesia are unknown. A prospective controlled study was performed in 16 ASA class I patients, who scheduled for spinal anesthesia for urological and gynecological procedures. The subjects were randomly allocated into two groups. Group I $(n=8)$ received triazolam $0.25 \mathrm{mg}$ orally about 1 hour prior to anesthesia. Group II $(n=8)$ received clonidine $0.3 \mathrm{mg}$ orally about 1 hour prior to anesthesia. All patients received $15 \mathrm{mg}$ tetracaine in $3 \mathrm{~m} \ell$ normal saline.

No diference was observed between mean highest levels of sensory anesthesia. The mean times to two-and four-segment regression from the highest level were significantly longer in group II than in group I. Mean times for regression to the Th10 and $\mathrm{L}_{1}$ segment were also significantly longer in group II than in group I.

These findings show us that oral clonidine premedication produces a significant prolongation of the duration of spinal anesthesia with tetracaine.

The Journal of Japan Society for Clinical Anesthesia Vol. 9 No. 2, 1989 